\title{
PEMAHAMAN ORANG TUA TERHADAP PENTINGNYA PENDIDIKAN ANAK USIA DINI
}

\author{
Helly Apriyanti ${ }^{1)}$ \\ 1) IKIP PGRI Jember \\ helly982@yahoo.co.id
}

\begin{abstract}
ABSTRAK: Pendidikan anak usia dini tentunya tidak bisa diabaikan dari peran orang tua. Orang tua tentunya harus memahami akan pentingnya pendidikan bagi anak usia dini. Hal ini dimaksudkan agar pembentukan karakter bagi anak sudah ditanamkan sejak dini. Tujuan diadakannya penelitian deskriptif ini mengetahui sejauh mana orang tua memahami akan pentingnya pendidikan anak usia dini. Penelitian ini dilaksanakan di Desa Wancimekar Kecamatan Kotabaru Kabupaten Karawang, dengan populasi warga kampung Kalioyod dan sampelnya dilakukan dengan simple random sampling. Hasil analisis data yang sudah diolah menyimpulkan bahwa $78 \%$ orang tua memahami tentang sangat pentingnya pendidikan anak usia dini, sehingga dapat disimpulkan bahwa orang tua sudah paham akan pentingnya pendidikan anak usia dini.
\end{abstract}

Kata kunci : Pemahaman, Orang Tua, Pendidikan Anak Usia Dini

ABSTRACT: Early age child education can not be neglectful from their parent's action. Parents have to understand about important of education for the early age child. That means character building for child has planted from early. Purpose of this research to know, as far as understanding of parents from important of early age child education. This research is done at Desa Wancimekar Kecamatan Kotabaru Kabupaten Karawang, which is population of kalioyod village citizen and the sample is done simple random sampling. Data analysis result which has been processed concludes that $78 \%$ of parents understand that is very important about education is important for early age child, so it can be concluded that parents have understood with early age child education.

Keywords: Understanding, Parents, Eearly Age Child Education.

\section{PENDAHULUAN}

Semakin berkembang dan majunya dunia pendidikan, semakin berkembang pula lembaga pendidikan yang menyediakan layanan Pendidikan anak usia dini (PAUD). Pendidikan anak usia dini (PAUD) dimaksudkan bahwasannya pendidikan yang menyiapkan anak untuk dapat mengikuti pendidikan lebih lanjut. Usia 0-6 tahun merupakan masa dimana anak dapat dengan cepat menerima rangsangan. Pada usia ini sangat penting mengembangkan segenap potensi yang dimiliki anak.

Anak merupakan titipan sang Ilahi, seyogyanya orang tua bersyukur atas apa yang telah diberikan oleh Sang Pencipta. Mendidik anak diawali dalam keluarga, yang pada nantinya akan beradaptasi di sekolah juga masyarakat. Anak usia dini memiliki tahapantahapan dalam perkembangannya, untuk itu dalam mendidik anak tentunya harus sesuai dengan tahapannya. 
Anak sebagai individu yang utuh, atau whole child yang dalam perkembangannya meliputi aspek : fisik, sosial, emosional, bahasa, kesadaran budaya, intelektual dan kreatif yang tidak dapat dipisahkan satu sama lainnya (Lindon dalam Halimah, 2016). Konsep "the whole child" yang dikemukakan oleh Gordon dan Browne menggambarkan semua aspek pertumbuhan dan perkembangan anak yang terintegrasi, saling terkait dan saling mendukung (Halimah, 2016). Aspek nilai agama dan moral mengembangkan kemampuan anak berkaitan dengan prilaku baik, aspek fisik motorik untuk mengembangkan kematangan kinestetik, aspek kognitif untuk mengembangkan kematangan proses berfikir, aspek bahasa untuk mengembangkan kematangan bahasa, aspek sosial emosional untuk mengembangkan kepekaan, sikap dan keterampilan sosial, aspek seni untuk mengembangkan eksplorasi, ekspresi, dan apresiasi seni.

Sebagai upaya mengembangkan keenam aspek perkembangan anak tentunya sangat penting peran guru, orang tua juga masyarakat. Peran orang tua tentunya sangatlah penting, karena pendidikan yang paling utama berada di dalam keluarga, maka orang tua tentunya memberikan pendidikan yang pertama. Orang tua dimana terdiri dari ayah dan ibu, memberikan kasih sayangnya semenjak janin masih dalam kandungan sang ibu. Ayah dan ibu harus memahami perkembangan sejak dalam kandungan dan memperhatikan asupan gizi yang baik untuk ibu dan janin. Begitupun sejak anak dilahirkan, orang tua memberikan kasih sayangnya untuk tumbuh kembang anak dengan baik.

Ibu dan ayah merupakan pendidik yang utama di dalam lingkungan keluarga bagi anak-anak mereka, karena orang tua memberikan pendidikan utama untuk putra-putrinya. Untuk itu sangat jelas bahwa pendidikan utama berawal dari keluarganya. Ibu ayah memberikan peranan yang penting bagi putra putrinya. Anak mendapatkan pendidikan pertama atau awal didapat dari ayah dan ibunya. Anak juga mendapatkan pendidikan dari orang dewasa yang berada di dalam rumahnya. Rumah menjadikan sekolah awal bagi anak sebelum anak masuk kedalam lingkungan di sekolah.

Anak-anak hidup dan berinteraksi dengan lingkungan sosial, termasuk dengan anggota keluarga, pamong sekolah atau petugas lembaga, dan teman-teman sepermainannya (Suyadi \& Ulfah, 2012). Artinya kita tahu anak hidup dalam lingkungan keluarga juga lingkungan sekolah, sehingga orang tua dan guru hendaknya menjalin kerjasama dalam pendidikan anak untuk mengembangkan kompetensi anak.

Kerjasama orang tua, guru juga masyarakat diperlukan dalam pengembangan anak usia dini. Orang tua menyekolahkan putra-putrinya untuk dapat memberikan kesempatan anak mampu bersosialisasi dengan anak seusiannya. Guru memberikan fasilitas dalam pengembangan potensi yang dimiliki oleh anak. Begitu juga dengan masyarakat tentunya harus memberikan lingkungan aman nyaman dalam pendidikan bagi anak usia dini. Allen (Halimah, 2016) menjelaskan yang harus diperhatikan oleh orang tua dan pendidik dalam membantu tumbuh kembang anak, sebaiknya difokuskan pada upaya memenuhi berbagai kebutuhan, diantaranya kebutuhan fisik, kebutuhan psikologis, 
kebutuhan untuk belajar dan kebutuhan untuk dihargai sebagai individu yang mempunyai harga diri.

Delapan intelegensi menurut Gardner (Wijana, 2010) meliputi kecerdasan linguistik, logika-matematika, visual-spasial, musikal, kinestetis, naturalis, interpersonal dan intrapersonal. PAUD merupakan salah satu jenjang pendidikan yang berupaya memberikan layanan pendidikan yang fundamental secara bermutu sesuai dengan usia, perkembangan potensi individu anak, dan sosial -budaya kehidupan anak (Halimah, 2016).

Fungsi PAUD menurut Wijana (2010) adalah fungsi adaptasi, fungsi sosialisasi, fungsi pengembangan dan fungsi bermain. Menurut Feed Rogers (Halimah, 2016) dalam PAUD, anak-anak harus menjadi pusat dari semua yang orang dewasa pikirkan dan lakukan, dan orang dewasa harus menghormati keunikan setiap anak dan keluarga mereka. Menurut Kehily (Halimah, 2016) pendidikan anak usia dini mempunyai tanggung jawab untuk memberikan pendidikan yang sesuai, membimbing serta mengawasi anak-anak agar berkembang menjadi warga negara yang bertanggung jawab.

\section{METODE PENELITIAN}

Metode penelitian deskriftif dipilih dalam penelitian ini untuk mendeskripsikan seberapa besar pemahaman orang tua terhadap pentingnya pendidikan anak usia dini. Subjek penelitian ini yaitu orang tua yang ada di kampung Kalioyod Desa Wancimekar. Populasi sebanyak 100 dan diambil sampel sebanyak 50 orang tua.

Untuk mendapatkan gambaran tentang pentingnya pendidikan anak usia dini maka dilakukan pengisian sejumlah angket berupa 15 daftar pernyataan yang harus diisi orang tua agar dapat diberikan gambaran secara jelas seberapa besar pemahaman orang tua terhadap pentingnya pendidikan anak usia dini.

Adapun angket yang disebarkan kepada 50 sampel dengan menggunakan skala likert sebagai berikut :

\section{Gradasi}

Sangat Paham (SP)

Paham (P)

Kurang Paham (KP)

Tidak Paham (TP)

Sangat Tidak Paham (STP)

\section{Skor}

: 5

: 4

: 3

: 2

: 1 
Menghitung prosentase dari hasil pengolahan data yaitu menggunakan statistik sederhana acuan dari Anas Sudjono (2003:43) yaitu :

$$
p=\frac{f}{n} x 100 \%
$$

Keterangan :

$$
\begin{array}{ll}
\mathrm{P} & =\text { Angka presentase } \\
\mathrm{F} & =\text { Frekuensi yang sedang dicari persentasenya } \\
\mathrm{N} & =\text { Jumlah frekuensi/banyaknya individu } \\
100 \% & =\text { Bilangan tetap }
\end{array}
$$

\section{HASIL DAN PEMBAHASAN}

\begin{tabular}{|c|c|c|c|c|c|c|c|c|c|}
\hline \multirow[t]{2}{*}{ No } & \multirow[t]{2}{*}{ Pernyataan } & $\begin{array}{c}\text { Sangat } \\
\text { Paham } \\
\text { (5) }\end{array}$ & $\begin{array}{c}\text { Paham } \\
\text { (4) }\end{array}$ & $\begin{array}{l}\text { Kurang } \\
\text { Paham } \\
\text { (3) }\end{array}$ & $\begin{array}{l}\text { Tidak } \\
\text { Paham } \\
\text { (2) }\end{array}$ & $\begin{array}{c}\text { Sangat } \\
\text { Tidak } \\
\text { Paham } \\
\text { (1) }\end{array}$ & \multirow[t]{2}{*}{ Skor } & \multirow[t]{2}{*}{$\begin{array}{l}\text { Persen } \\
\text { tase }\end{array}$} & \multirow[t]{2}{*}{ Kategori } \\
\hline & & $\mathbf{f}$ & $\mathbf{f}$ & $\mathbf{f}$ & $\mathbf{f}$ & $\mathbf{f}$ & & & \\
\hline 1 & item 1 & & 20 & 30 & & & 170 & 68 & Paham \\
\hline 2 & item 2 & & 17 & 33 & & & 167 & 66,8 & Paham \\
\hline 3 & item 3 & & 15 & 35 & & & 165 & 66 & Paham \\
\hline 4 & item 4 & & 50 & & & & 200 & 80 & $\begin{array}{l}\text { Sangat } \\
\text { paham }\end{array}$ \\
\hline 5 & item 5 & & 50 & & & & 200 & 80 & $\begin{array}{l}\text { Sangat } \\
\text { paham }\end{array}$ \\
\hline 6 & item 6 & & 50 & & & & 200 & 80 & $\begin{array}{l}\text { Sangat } \\
\text { paham }\end{array}$ \\
\hline 7 & item 7 & & 50 & & & & 200 & 80 & $\begin{array}{l}\text { Sangat } \\
\text { paham }\end{array}$ \\
\hline 8 & item 8 & & 10 & 40 & & & 160 & 64 & Paham \\
\hline 9 & item 9 & 50 & & & & & 250 & 100 & $\begin{array}{l}\text { Sangat } \\
\text { paham }\end{array}$ \\
\hline 10 & item 10 & 50 & & & & & 250 & 100 & $\begin{array}{l}\text { Sangat } \\
\text { paham }\end{array}$ \\
\hline 11 & item 11 & & 38 & 12 & & & 188 & 75,2 & Paham \\
\hline
\end{tabular}

Desa Wancimekar berada di Kecamatan Kotabaru Kabupaten Karawang Jawa Barat. Uraian hasil dari pengolahan data penelitian yang dilakukan di Desa Wancimekar sebagai berikut :

Tabel 1. Hasil Wawancara 


\begin{tabular}{|c|c|c|c|c|c|c|}
\hline 12 & item 12 & 32 & 18 & 182 & 72,8 & Paham \\
\hline 13 & item 13 & 44 & 6 & 194 & 77,6 & Paham \\
\hline 14 & item 14 & 42 & 8 & 192 & 76,8 & Paham \\
\hline 15 & item 15 & 50 & & 200 & 80 & $\begin{array}{l}\text { Sangat } \\
\text { paham }\end{array}$ \\
\hline & \multicolumn{4}{|c|}{ Rata-rata } & 78 & Paham \\
\hline
\end{tabular}

Berdasarkan tabel di atas, terlihat bahwa secara umum orang tua sudah paham akan pentingnya pendidikan anak usia dini. Dari 15 item pernyataan tabel di atas terlihat jelas item 4, 5, 6, 7, 9, 10 dan 15 rata-rata orang tua sangat paham tentang layanan PAUD usia 4 sampai 6 tahun, peran orang tua sebagai teladan bagi anaknya dan juga orang tua sebagai pengawas, dan juga tentang posyandu. Sedangkan item 1, 2, 3, 8, 11, 12, 13, dan 14 orang tua sudah paham namun perlu ditingkatkan lagi pemahamannya tentang pembinaan yang ditujukan kepada anak usia dini, layanan pendidikan usia 0- 4 tahun, aspek perkembangan anak, kerjasama orang tua dan guru. Setelah diuraikan dalam tabel di atas didapat rata-rata $78 \%$ pemahaman orang tua di Desa Wancimekar sudah paham akan pentingnya pendidikan anak usia dini.

\section{KESIMPULAN}

Sebagaimana telah diuraikan di atas maka orang tua di Desa Wancimekar sudah paham akan pentingnya pendidikan anak usia dini. Adapun prosentase pemahaman berada pada $78 \%$.

\section{DAFTAR PUSTAKA}

Halimah, Leli. (2016). Pengembangan Kurikulum Pendidikan Anak Usia Dini. Bandung: PT. Refika Aditama

Sudjono, Anas. (2003). Statistik Pendiidikan. Jakarta : Rajagrafindo Persada

Sugiyono. (2016). Metode Penelitian Kuantitatif, Kualitatif dan R\& D. Bandung : Alfabeta

Suyadi, dan Ulfah. (2012). Konsep Dasar PAUD. Bandung : PT. Remaja Rosdakarya

Wijana, Widarmi D. (2010). Kurikulum Pendidikan Anak Usia Dini. Jakarta : Universitas Terbuka 
Volume 3, Nomor 1, Februari 2019 